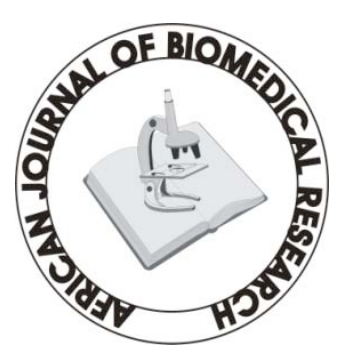

Full-text available at http://www.ajbrui.com http://www.bioline.br/md http://www.ajol.com

Received:

January 2008

Accepted (Revised): June 2008

Published

Septemeber 2008
Full Length Research Article

\section{Effect of Malaria on Rural Households' Farm Income in Oyo State, Nigeria.}

\author{
*Ajani, O.I.Y and W.M. Ashagidigbi \\ Department of Agricultural Economics, \\ University Of Ibadan, Nigeria
}

\begin{abstract}
Malaria is one of the commonest tropical diseases plaguing the African continent and the rural areas of the continent in particular. Hence this study was carried out to analyze the effect of malaria on the overall farm income of the rural households, the level of awareness and use of modern preventive measures of treating malaria in Ido Local Government Area, classified as rural in Oyo State. Stratified random sampling procedure was employed for the research survey in which the first level of stratification involved the random selection of one Local Government Area (LGA), the second level of stratification was that of selection of four villages and the third level of stratification was the selection of twenty five households each from the villages. A total number of 100 respondents were finally used for data analysis using both descriptive and multiple regression techniques. Low level of awareness, $(56 \%)$, use of modern preventive measures $(12 \%)$, poor sanitary conditions, and large household size (8 persons), were the major factors responsible for the high malaria incidence in the rural household. The increase in malaria incidence however had a significant effect on the health and farm income of the farmers through increase in the number of days of incapacitation of an average of 22 days and an income loss of $\$ 15231.50$ during the days of incapacitation. The recommended policies arising from the economic implications of these empirical findings were that public enlightenment under the aegis of the "Roll Back Malaria Campaign" should be intensified in the rural areas in particular and treated mosquito bed nets provided at subsidized rates to rural households. Farmers on their part should keep clean environment.
\end{abstract}

(Afr. J. Biomed. Res. 11: 259- 266)

Key words: malaria, environment, agricultural farm income. Incapacitation, awareness of preventive measure.

*Corresponding author

Abstracted by:

African Index Medicus (WHO), CAB Abstracts, Index Copernicus, Global Health Abstracts, Asian Science Index, Index

Veterinarius, Bioline International, African Journals online 


\section{INTRODUCTION}

Among the major diseases that are common in Africa, Malaria is one of the greatest threats facing development in Africa today. It attacks an individual on average of four times in a year with an average of 10 to 14 days of incapacitation (Alaba and Alaba, 2002). Recent estimate indicates that between 700,000 and 2.7 million people die annually from malaria. Over 75 percent of these mortality figures are African children (Multilateral Initiative on Malaria (MIM), 2001). In addition to its health impact, malaria is an obstacle to social and economic development.

According to recent estimates the direct and indirect costs of malaria exceeded US $\$ 2$ billion in 1997 and this figure is likely to increase every year. (Alaba and Alaba, 2002) Furthermore, on a global perspective between 400 and 900 millions of children under the age of 5 experience acute malaria annually in this malaria endemic region and that this number may double by year 2020 if effective control measures are not implemented (Multilateral Initiative on Malaria (MIM), 2001). Malaria, is not only a health problem, it is also an economic problem. Malaria at the household level affects productivity of the people and their assets acquisition capacity. Households also frequently spend substantial share of their income and time on malaria prevention and treatment as well as an effort to control mosquitoes (Coluzzi, 1999). The cost of prevention and treatments consumes scarce households' resources. Also as some household members spend their productive time caring for those under malaria attack, they themselves in turn seek rescue from the onslaught of the disease (Mills, 1998).

Malaria therefore has a direct impact on households' income, wealth, labour productivity and labour market participation of both the sick and the caregivers. In terms of resource loss, households spend between $\$ 2$ and $\$ 25$ on malaria treatment and between $\$ 20$ and $\$ 15$ on prevention each month (Mills, 1998). As much as 13 percent of total small farming households expenditure in Nigeria is currently being used in treating malaria, while many are simply too poor to pay for adequate prevention and treatment of the disease
(WHO, 1999).

The loss to households may however be greater with the current trend in malaria resistance to traditional first-line drugs. Such loss has serious implication for poor household who are already malnourished, who live under pitiable condition and who constitute over 65 percent of the nation's population (FOS 1999).

Calculating the loss of productivity or productive potential resulting from sickness involves the application of some consensual economic principles. Earnings, which include wages, salaries and other remunerations other than transfers have been theoretically and generally accepted as an appropriate measure of workers productivity. Some pioneers on the empirical assessment of the impact of health status on productivity did so by relating health status to earnings and other income-generating potentials

The American Association for the Advancement of Science, 1991 claimed that approximately 80-85 percent of the cases of population morbidity and mortality in SubSaharan Africa are attributable to Malaria. The malaria problem has at leat three dimensions- the health, the social and the economic dimensions. The health problem is evidenced by high malariarelated mortality and morbidity in many African countries, Nigeria included. Malaria deaths in SubSaharan Africa amount to some 0.5 to two million deaths per year, with children accounting for 0.75 to one million of these deaths (Snow et al., 1997; Okorosobo, 2000). The disease afflicts mainly pregnant women, young children, migratory populations and persons with little previous exposure to malaria attacks (Snow, et al., 1997).

The Organization of African Unity says that by the year 2000, it would have cost African economy \$3.6 billion in a year as a result of working hours lost and the cost of treatments. Rural households unlike the fixed wage earners not only lose valuable working hours in treating the sickness but also lose income that would have been generated at this period. This poor health status thus directly affects the productive capacity of the households. This in turn translates into income loss and eventually poverty through the sick and the caregivers to the households. 
However, at the core of the magnitude of malaria in Africa, is the environment, which is highly conducive to malaria transmission.

The issue of poverty is also at the roots of the malaria giant' in Africa (Coluzzi, 1999). Poverty impacts on self-treatment, health seeking behaviour and capacity for disease prevention at home and community level. In the public sector, poverty generates underdeveloped health services, with poor quality of care and low coverage of the population, which in some countries may be as low as 30-40 percent.

Civil wars and conflicts have further complicated the problem, creating disruption among the impoverished population destroying the weak infrastructure and increasing the size of the refugee populations. Displaced populations across borders or even internally in some countries are highly vulnerable to malaria ravages during epidemics. Other important bottlenecks of malaria control in Africa include the insufficient allocation of resources by national governments to malaria control, large dependency on external aid and inadequate support from the international community to seriously reduce malaria morbidity and mortality in Africa.

The major objective of this study is to estimate the effect of malaria on the farm income of the rural households in Oyo State, while the specific objectives are to ascertain the level of awareness of households' to modern preventive measures, the days of incapacitation and the income lost due to malaria illness.

\section{METHODOLOGY}

\section{(i) Study Area}

The study area is Ido Local Government Area, in Ibadan, Oyo State, Nigeria. The Local government headquarters is at Ido, a place situated along Ibadan - Eruwa road. According to 1991 population census, Ido local government had the total population of 53,582 people while it was 61,847 according to 1996 projection while it was 61,847 according to 1996 projection given a growth rate of 2.3 percent (FOS, 1999). The people of Ido are mainly small scale farmers with significant, proportion of the farmers engaging in secondary occupation such as hunting, trading, artisan, civil service jobs e.t.c. Farmers in the area grow mainly food crops such as maize, cassava, yam, vegetables e.t.c. They also engage in the cultivation of some cash crops like cocoa, kola, oil palm etc.

\section{(ii) Method of Data Collection}

Simple random sampling technique was employed for the research survey. The local government area was divided into 4 wards based on the geopolitical location and one village each was selected namely; Akufo, Ido, Omi-Adio and Idi-Iya representing Ido North, Central, South and East respectively.

Twenty-five farming households were therefore randomly selected, in each village to make a total of 100 respondents.

Structured and systematically drawn questionnaires as well as personal interviews were the data collection instruments. Data were collected on the socio-economic characteristics and also on malaria incidence as it affects rural household's health and their agricultural labour productivity.

\section{Regression Analysis of effects of Malaria on agricultural productivity}

In the regression analysis, the total income of the respondents represents the dependent variable (Y) i.e.

$\mathrm{Y}_{\mathrm{A}}=$ Total annual income of respondents in Naira

$\begin{aligned} \text { AGE } & =\text { Age in years } \\ \text { HHS } & \text { Household size } \\ \text { FM } & =\text { Farm size in hectares } \\ \text { TDA } & =\text { Total days of incapacitation } \\ \text { FDE } & =\text { Food expenditure in Naira } \\ \text { NFE } & =\text { Non-food expenditure in Naira } \\ Y_{T} & =\text { Total income lost due to malaria in Naira }\end{aligned}$

The implicit function is thus stated as: $\mathrm{Y}_{\mathrm{A}}=\mathrm{f}\left(\mathrm{AGE}, \mathrm{HHS}, \mathrm{FMS}, \mathrm{TDA}, \mathrm{FDE}, \mathrm{NFE}, \mathrm{Y}_{\mathrm{T}}\right)$

The different functional forms fitted were Semi$\log$, double $\log$, exponential and linear, and eventually, the best functional form was chosen on the basis of number of significant variables, signs of the coefficients, value of coefficient of 
determination $\left(\mathrm{R}^{2}\right.$ or $\left.\mathrm{R}^{-2}\right)$, F-value or economic reasoning and expectation.

\section{RESULTS AND DISCUSSION}

Socioeconomic characteristics of the sampled respondents are presented namely age, household size, farm size cultivated, and annual income from farming activities, and the total number of days that farmers were incapacitated from their farm work due to malaria infection. The result of the analysis shows that the average age of the farmers was 41 years, mean household size was 8 persons, and the average farm size was one hectare signifying that the farmers are small scale, and they use traditional tools in their farming activities. The average annual farm income was 119,690 (equivalent to $9,974.17$ per month), while the average days of incapacitation from farm work was given as 22 days in a year. All these are illustrated in tables 1,2,3,4 and 5. The implications of these on the objectives of the study are: (i) A larger percentage $(78 \%)$ of the farmers are still within the very active productive age group in which their farm productivity should be relatively high, given a healthy living condition devoid of malaria and other productivity diminishing problems.

Table 1:

Distribution of Farmers by Age

\begin{tabular}{lll}
\hline Age in years & Frequency & Percentage \\
\hline $0-20$ & 3 & 3 \\
\hline $21-30$ & 10 & 10 \\
\hline $31-40$ & 46 & 46 \\
\hline $41-50$ & 28 & 28 \\
\hline $51-60$ & 11 & 11 \\
\hline $61-70$ & 1 & 1 \\
\hline $71-80$ & 1 & 1 \\
\hline Total & 100 & 100 \\
\hline Average age & $\begin{array}{l}41 \text { years; } \\
\text { dev.=9.6 }\end{array}$ & Std \\
\hline Sourc: Field Survey, 2004. Std dev. Standardeviation
\end{tabular}

Source: Field Survey, 2004. Std dev.= Standard deviation
Table 2:

Distribution of Farmers by Household Size

\begin{tabular}{lll}
\hline Household size & Frequency & Percentage \\
\hline $0-5$ & 17 & 17 \\
\hline $6-10$ & 62 & 62 \\
\hline $11-15$ & 20 & 20 \\
\hline $16-20$ & 1 & 1 \\
\hline Total & 100 & 100 \\
\hline Average & $\begin{array}{l}\text { 8persons; } \\
\text { dev.=3.07 }\end{array}$ & std \\
\hline
\end{tabular}

Source: Field Survey, 2004; Std dev. = Standard deviation

Table 3:

Distribution of Farmers by the Farm size cultivated

\begin{tabular}{llll}
\hline $\begin{array}{l}\text { Farm } \\
\text { (acres) }\end{array}$ & Size & Frequency & Percentage
\end{tabular}

\begin{tabular}{lll}
\hline $0-2$ & 21 & 21 \\
\hline $3-5$ & 67 & 67 \\
\hline $6-8$ & 12 & 12 \\
\hline Total & 100 & 100 \\
\hline Average & 4 acres (1 hectare) & Std dev. $=\mathbf{1 . 4 7}$
\end{tabular}

Source: Field Survey, 2004; Std dev.= Standard deviation

Table 4:

Distribution of Farmers by annual Farm Income

\begin{tabular}{lll}
\hline Annual Income (N) & Frequency & Percentage \\
\hline $0-100,000$ & 51 & 51 \\
\hline $101,000-200,000$ & 37 & 37 \\
\hline $201,000-300,000$ & 11 & 11 \\
\hline $301,000-400,000$ & 1 & 1 \\
\hline Total & 100 & 100 \\
\hline Average & $¥ 119,690$ & $\begin{array}{l}\text { Std } \\
\text { dev.=N64443.80 }\end{array}$ \\
\hline Source: Field Survey, $2004 ;$ Stddev. Standard deviation
\end{tabular}

Source: Field Survey, 2004; Std dev.= Standard deviation

The average household size is 8 persons; this has implications for labour provision on the farm meaning increased productivity but its negative impact of overcrowding of residents in the home. One of the causes of high incidence of malaria is 
environmental stress and overcrowding could cause this. (iii) The average annual farm income of N 9,974.17 indicates very poor earning situation of the farmers signifying an earning of less than $\$$ 3.00 per day.

Table 5:

Distribution of Farmers by number of days of incapacitation due to Malaria

\begin{tabular}{lll}
\hline $\begin{array}{l}\text { Days of incapacitation } \\
\text { /year }\end{array}$ & Frequency & Percentage \\
\hline $0-15$ & 5 & 5 \\
\hline $16-20$ & 41 & 41 \\
\hline $21-25$ & 40 & 40 \\
\hline $26-30$ & 13 & 13 \\
\hline $31-35$ & 1 & 1 \\
\hline Total & 100 & 100 \\
\hline Average & 22 days & Std dev. $=4.42$ \\
\hline Source: Field Survey, 2004; Std dev. Standard deviation
\end{tabular}

Source: Field Survey, 2004; Std dev. = Standard deviation

Table 6:

Distribution of Farmers on the Use of Modern

Preventive Measures.

\begin{tabular}{lll}
\hline $\begin{array}{l}\text { Use of } \\
\text { preventive } \\
\text { measures }\end{array}$ & Frequency & Percentage \\
\hline Modern & 12 & 12 \\
\hline None & 88 & 88 \\
\hline Total & 100 & 100 \\
\hline
\end{tabular}

Source: Field Survey, 2004

Table 7:

Level of Awareness of Modern Preventive Medicine

\begin{tabular}{|l|l|l|}
\hline $\begin{array}{l}\text { Level of } \\
\text { Awareness }\end{array}$ & Frequency & Percentage \\
\hline Aware & 56 & 56 \\
\hline Not Aware & 44 & 44 \\
\hline Total & 100 & 100 \\
\hline
\end{tabular}

Source: Field Survey, 2004

Tables 6 and 7 tell the story about use of modern preventive medicine and the level of awareness of farmers about the availability of modern preventive medicine. it is interesting to note that 88 percent of the farmers use none of the modern preventive medicine and 44 percent of the farmers are not aware that there are modern ways of preventing malaria. This has implication on preventive and curative step taken to curb the infection of the illness in the study area, and to think of the fact that in this millennium, some set of people are still ignorant of preventive and curative measures suggests that deaths to this illness may still be regarded as an act of God. This does not justify the huge sums of money spent on the "Roll Back Malaria Campaign".

\section{Regression Analysis of effects of Malaria on agricultural productivity}

For the regression analysis, linear functional form gave the best fit and was chosen as the best functional form that explains the causal relationship between productivity proxy (Farm income) and malaria incidence, also proxy by the days of incapacitation. Based on the consideration of statistical and economic criteria the results are presented below:

Table 8:

Linear regression functional form showing the effect of malaria illness on the farm income of farmers

\begin{tabular}{|c|c|c|c|}
\hline Variables & Coefficients & $\mathrm{t}$ & Prob \\
\hline (Constant) & -27297.6 & -1.568 & 0.116 \\
\hline AGE & -363.33 & -1.164 & 0.247 \\
\hline HHS & $-2655.64 * *$ & -2.238 & 0.028 \\
\hline FMS & $10009.27 *$ & 4.681 & 0.000 \\
\hline$\overline{\mathrm{IDA}}$ & -387.551 & -0.553 & 0.582 \\
\hline FDE & $1.387 *$ & 4.668 & 0.000 \\
\hline NFE & $0.443^{*}$ & 2.813 & 0.006 \\
\hline$Y_{T}$ & $5.351 *$ & 10.124 & 0.000 \\
\hline $\begin{array}{r}\mathrm{Y}_{\mathrm{A}}=-2729 \\
\quad(1 \\
+10009.271 \\
5.351 \mathrm{YT} \\
(2138.55)^{*} \\
\mathrm{R}^{2}=0.864 \\
\mathrm{R}^{2}=0.854 \\
* \text { - Statistic: } \\
* * \text { - Statisti }\end{array}$ & $\begin{array}{l}-363.33 \mathrm{AGE}-265 \\
3.69)(312.135) \\
\text { MS-387.55IDA+1.38 } \\
700.953)(0.296)^{*} \\
\text { y significant at } 1 \mathrm{p} \\
\text { ly significant at } 5\end{array}$ & $\begin{array}{l}5.641 \mathrm{HHS} \\
(1186.513) \\
82 \mathrm{FDE}+ \\
(0.154)^{*}\end{array}$ & $\begin{array}{l}* * \\
0.433 \mathrm{NFE}+ \\
(0.529)^{*}\end{array}$ \\
\hline
\end{tabular}

From the implicit function given above, the $\mathrm{R}$ squared value is 0.864 , showing that 86.4 percent 
of the change that occurred in the dependent variable can be explained by the explanatory variables. This also shows that the model produces a good fit for the data.

Farm size, food expenditure, non-food expenditure and total income lost due to malaria are statistically significant at one percent while household size is statistically significant at five percent. However, age and days of incapacitation are not statistically significant at ten percent in explaining the variation in the annual income realized from the farm which is a proxy used to measure productivity of farmers.

However, the negative beta coefficient of age implies that farmers' income decreases with increase in age. This is expected because productivity of farmers decreases as they approach old age because of loss of agility and strength.

The negative beta coefficient of household size is also expected as increase in households size increases expenditure and this decreases farmers' annual income.

Annual income also decreases with increase in days of incapacitation because the more the number of days, the greater the loss incurred during treatment, and the lesser the annual income.

Also, farm size has a positive beta coefficients indicating that annual income increases with increase in acreage of land cultivated. The positive beta coefficients of food and non-food expenditure show increase in expenditure as income of farmers' increases. This is expected because the greater the income of the farmers, the more they tend to spend on food and non-food items.

Lastly, total income lost due to malaria also has a positive beta coefficient, which means that as income increases; income lost due to malaria also increases. This is true because high income earning farmers tend to lose more of their income due to better treatment they seek which attracts high cost, and also because of income lost during the period of incapacitation which tends to be more compared to the low income earning farmers.

\section{Conclusion}

Malaria is both a health and economic problem eating deeply into the financial base of the victims or the caregivers. Malaria has become a menace in Africa, especially in rural areas because of low level of awareness and use of modern preventive measures against mosquitoes that causes malaria.

Apart from this, large household size, which is a common feature of rural people, has been a cause of increase in malaria incidence. Families with large household size usually have low income, which in turn increases their poverty status. The use of preventive measures and proper treatment of malaria cases thus become almost impossible. In addition to this, poor sanitary condition of farmers is also one of the major causes of high malaria incidence in the rural areas. Furthermore, increase in malaria incidence increases days of incapacitation, this in turn increases the total income that is lost due to malaria, and finally there is a significant reduction in the productivity and also the income of the farmers. Health risks and poverty thus become a vicious cycle in the rural areas.

\section{Recommendations}

- There should be interventions in form of mobilizing resources, formulating and implementing policies and programmes that will promote awareness and measures that ensure effective prevention and control of the pandemic disease.

- Hospitals and clinics should also be easily accessible, readily available and affordable to the farmers in order to meet their health needs.

- Medication that can reduce the days of incapacitation should be intensified and made available to farmers at affordable prices in order to improve the quality of life and productivity of farmers.

\section{REFERENCES}

Alaba, O.A. and Alaba, O. B. (2002): "Malaria in Children. Implications for the productivity of female caregivers in Nigeria". Proceeding of Annual Conference of the Nigerian Economic Society (NES), pp 395-413.

Coluzzi. M. (1999): "The Clay feet of the malaria giant and its African roots: hypotheses and 
inferences about origin, spread and control of plasmodium falciparum". Parasitologia. 41: 277283.

Federal Office of Statistics (FOS): (1999): Poverty Profile for Nigeria, 1980-1996. Abuja. pp 33-44

Mills, A. (1998): Operational Research on the Economics of Insecticide Treated mosquito nets: Lesson of Experience. Annals of Tropical Medicine and Parasitology 92(4).

Multilateral Initiative of Malaria (MIM), (2001): The Intolerable burden of Malaria. A new Look at Numbers. The American Journal of Tropical Medicine and Hygiene. Vol. 56(4) pp 282-287

Okorosobo, T (2000): "The Economic Burden of
Malaria in Africa", Paper prepared for the Abuja Summit of Heads of State and Government, Abuja, Nigeria, April.

Snow, R.W., Omumbo, J.A., Lowe, B., Molyneux, C.S., Obiero, C.S., Palmer, J.O., Weiber, A., Pinder, M.W., et al., (1997): "Relation between Severe Malaria Morbidity in Children and level of Plasmodium falciparum transmission in Africa". Lancet, 1:1650-1654.

World Health Organization (WHO) (1999): The World Health Report: Making a Difference. Geneva Switzerland: World Health Organization. $59 \mathrm{p}$

World Health Organization (2000): Malaria Desk Situation Analysis—Nigeria.120p 